\title{
RANGE EXTENSIONS OF TWO RARE ALBERTA SHRUBS
}

\author{
by J. KUIJT* AND J. A. TROFYMOW*
}

This note reports interesting range extensions for two rare Alberta shrubs, the Rocky Mountain Juniper (Juniperus scopulorum Sarg.) and the Mock Orange (Philadelphus Lewisii Pursh).

A single isolated tree of the Rocky Mountain Juniper was discovered by one of us (J.A.T.) in the Oldman River valley directly north of Lethbridge. The tree is 12'4" tall and has the typical upright form encountered throughout its normal geographic range (Fig. 1). Several of the lower branches on the northeast (leeward) side have become partially buried and have grown into erect, secondary stems. The main trunk is about 14 " in circumference at the base. A core extracted from the lowest portion showed approximately 45 rings.

The tree is located just above the floor of the main valley, in the lower portion of a coulee which runs to the north. Although the tree is, therefore, in a somewhat protected site, the photograph shows that it is not in a ravine, but is surrounded by common low coulee vegetation, including the only other juniper which occurs locally, the Creeping Juniper (Juniperus horizontalis Moench). There are neither trails nor roads in the im-

\footnotetext{
*Department of Bilogical Sciences,

University of Lethbridge.
}

mediate vicinity, nor evidence of any past habitation. A collection has been deposited in the University of Lethbridge Herbarium (Kuijt and Trofymow No. 4745).

A search at the relevant herbaria, in cluding the National Museum at $\mathrm{Ot}$ tawa, shows that Juniperus scopulorum so far is known only from three separate areas in Alberta, all withir the mountains, and usually on dry south-facing slopes. Moss suggestec that some semi-erect individuals in the Banff and Crowsnest Pass area hat been produced by browsing. ${ }^{3} \mathrm{Dr}$. Va Geist (University of Calgary; pers comm.) confirms that junipers are ar important browse plant for mule dee and, in certain regions, for mountair sheep. However, the individuals Mos referred to are more likely to be inter mediates between $J$. scopulorum and $J$ horizontalis, as are certain Waterto Lakes specimens present in th University of Lethbridge Herbarium. Typical erect Rocky Mountain Junipe is also known from Waterton Lakes. I the Crowsnest Pass, typical shrubs ma be seen on dry, southern exposures a far east as the western edge of th Frank Slide. Dr. Keith Shaw (Card ston; pers. comm.) also reports single, isolated small tree at Glenwoo near Cardston (Sec. 34 T4 R27 W4 These two localities are some 70 an 40 miles distant, respectively, from th Lethbridge tree. The tree would therefore, seem to represent remarkably clear-cut example o natural long-distance dispersal 


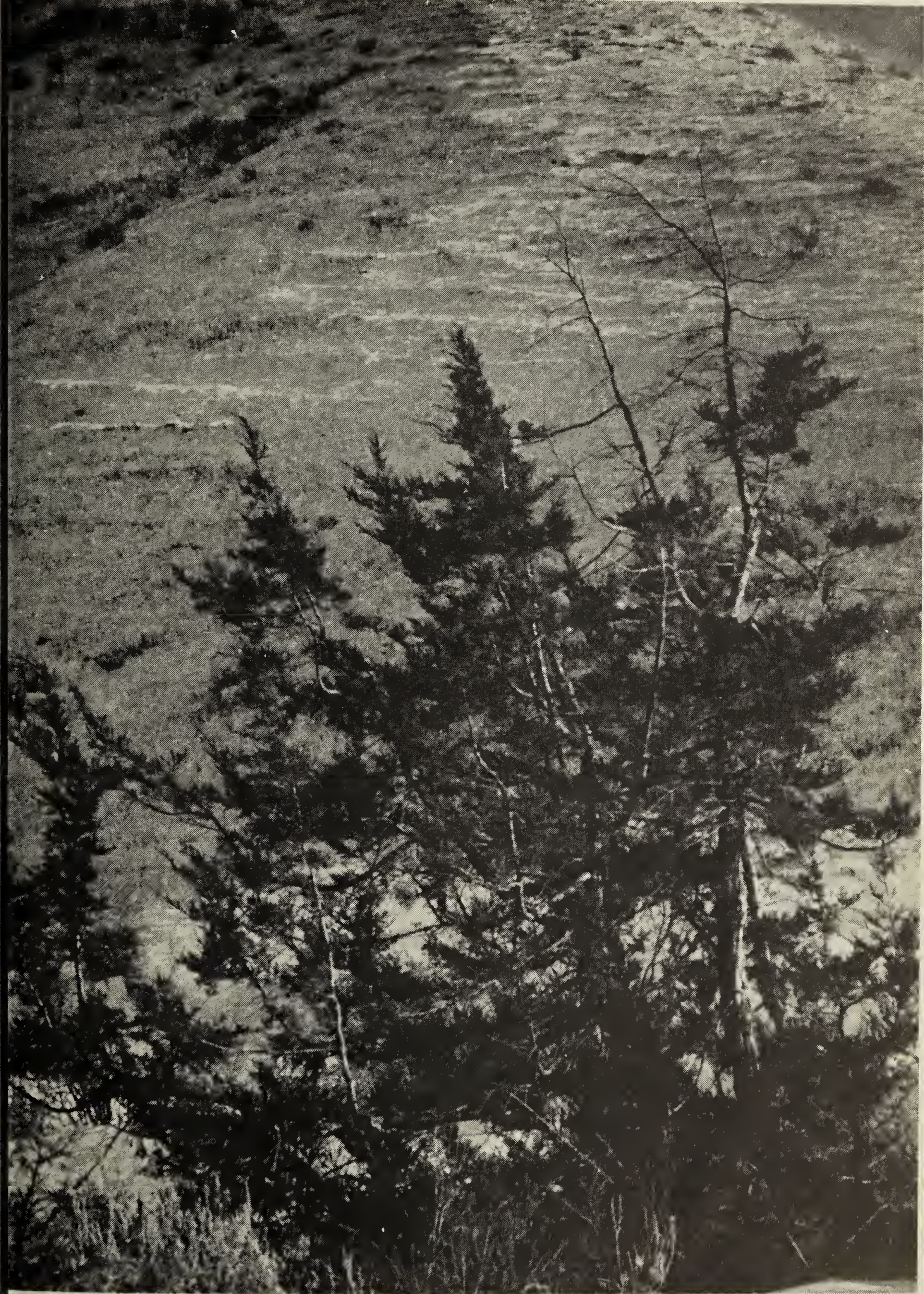

g. 1. Rocky Mountain Juniper in the Oldman. River Valley north of Lethbridge.

J. A. Trofymow 
Juniper berries are said to be eaten readily by many animals, the seeds not being digested.'

The Mock Orange is a common and decorative shrub in the valleys east of the continental divide, but in Alberta it has so far been known only in the Waterton Lakes area, where it grows very sparsely on a few rock outcroppings on the southern slope of $\mathrm{Mt}$. Crandell near the townsite. It also grows luxuriantly in a small, eastfacing ravine just north of the former locality. In the summer of 1974 , a small colony of this shrub was discovered on the lower south-facing slopes of an unnamed ridge of red shale on the Alberta side of Mt.
Darrah, west of Pincher Creek. A specimen from this locality has been deposited at the University of Lethbridge Herbarium (Kuijt No. 4743). The similarity of the site to that of the first-mentioned Waterton site was striking. It seems entirely possible that other, comparable southern slopes between Mt. Darrah and Waterton Lakes will yield further specimens of this attractive shrub.

'HITCHCOCK, C. L., A. CRONQUIST, and M OWNBEY. 1969. Vascular plants of the Pacific Northwest. Vol. I. Univ. Washington Press Seattle.

"KUIJT, JOB. 1973. New plant records in Waterton Lakes National Park, Alberta. Can. Field-Nat. 87:67-69

"MOSS, E. H. 1959. Flora of Alberta. Univ Toronto Press.

\title{
TODAY'S WEEDS - TOMORROW'S VEGETABLES
}

\author{
by AL GRASS*
}

The other day I read an article in a garden magazine regarding "weeds" and it has prompted me to offer the following comments.

I would like to suggest that one man's weed is another man's wildflower. A weed, it seems, is a plant which competes with more "suitable" plant varieties. Should not a rose bush in a carrot patch be considered a weed? After all, it is stealing nutrients from the tasty carrot.

Some of our most beautiful wildflowers are weeds:

\section{"Fringing the stream at every turn \\ Swing low the waving fronds of fern; \\ From stoney cleft and mossy sod}

Pale asters spring and golden rod."
Every garden should have a weer patch. This has a dual purpose - te encourage small birds and insects to visit with you and so that you will have some weeds to study and admire. Wha better way to spend one's time than to cultivate dandelions for sparrows anc finches?

Have you ever thought that today' weeds may be tomorrow's vegetables We can imagine such tasty treats a creamed Stellaria on toast wedges an sweet pickled pigweed. Even today w can enjoy such treats as lamb's quar ters and dandelion greens.

Nothing is worse than a garde without weeds. Give me a weed patc anytime. There is a thousand-fol more to admire in weeds than in thei sickly pampered garden kin.

\footnotetext{
*From The Victoria Naturalist, 31(9) May, 1975.
} 